\title{
Effect of heavy metals on soil microbial processes and population
}

\author{
Al Gaidi. Abdousalam \\ Faculty of Agriculture, Sebha University, Libya \\ E-mail: algaidiaa@yahoo.com \\ Address: SEBHA. LIBYA. P.O.Box 19988
}

\begin{abstract}
The effect of different toxic heavy metals ions was studied on the $\mathrm{CO}_{2}$ production of microorganisms in uncultivated sandy clay soil. The soils were treated by $\mathrm{C}, \mathrm{N}$ and $\mathrm{P}$ in the form of sodium nitrate, potassium phosphate and glucose respectively. The inhibitions appeared even affecting three weeks, but highly significant effects could be estimated after six-week incubation period. Cobalt ions had smallest effect on decreasing $\mathrm{CO}_{2}$-production in uncultivated soil samples at the different incubation intervals .The strongest inhibition of the gas production was detected by the influence of cadmium ions.
\end{abstract}

Keywords: cadmium, cobalt, $\mathrm{CO}_{2}$-production, soil microbial activities.

\section{INTRODUCTION}

The gradual increase in atmospheric $\mathrm{CO}_{2}$ concentration and potential climatic changes are likely to affect plant, soil and ecosystem processes, including carbon flux from plants to soil and from soil to atmosphere (Pajari, 1995). In a typical forest ecosystem, the components of soil $\mathrm{CO}_{2}$ efflux include (1) respiration due to litter decomposition, (2) root respiration, (3) rhizo-microbial respiration (i.e. microbial respiration utilizing $\mathrm{C}$ directly derived from living roots), and (4) microbial respiration utilizing native soil organic matter (Cheng, 1999).

Bayoumi and Kecskés (2008) mentioned that the biological activity in a soil is usually evaluated by measuring $\mathrm{CO}_{2}$ evolution. The results obtained from different studies on the influences of heavy metals on $\mathrm{CO}_{2}$ evolution in contaminated soils by the addition of sewage sludge have been at variance. It was established that the addition of sewage sludge containing high amount of $\mathrm{Cd}, \mathrm{Pb}$ to the soil increase the $\mathrm{CO}_{2}$ evolution. Soil respiration and microbial biomass can be useful indicators of soil contamination, combining the two measurements to give amounts of $\mathrm{CO}_{2}$ evaluated per unit of biomass $(\mu \mathrm{g}$ $\mathrm{CO}_{2}-\mathrm{C} / \mathrm{g}$ soil).

Soil microorganisms, the living component of soil organic matter, are responsible for mineralization of nutrients, decomposition, and degradation or transformation of toxic compounds. Being a labile fraction of soil organic matter, the microbial biomass can be a useful early indicator of change and future trends and can reflect organic matter changes and soil development.

The microbial biomass in soils comprises a substantial pool of nutrients, which depending on the stage of growth, can be a source or sink of plant nutrients. Close relationship between microbial biomass and soil fertility indices has been noted. Mineralizable $\mathrm{N}$ has been related to microbial $\mathrm{C}$ and $\mathrm{N}$ in a wide range of soils. It has been shown that a considerable proportion of the enhanced level of $\mathrm{N}$ and $\mathrm{P}$ in soils after 
drying is derived from the microbial cells killed by desiccation.

Microorganisms play a unique role in the soil ecosystem, because of their contributions to soil fertility. Contrasting trends, reported on toxic effects of heavy metals including $\mathrm{Cd}$, $\mathrm{Pb}$ on soil microorganisms and their activities, are attributable to short-term studies often limited to a single soil type and conducted under controlled laboratory conditions.

The bioavailability of $\mathrm{Cd}, \mathrm{Pb}$ and associated toxicity to soil biota vary with time, soil type, speciation, ageing, $\mathrm{Cd}, \mathrm{Pb}$ sources, organisms, and the environmental factors. The available fraction or soil solution $\mathrm{Cd}$, $\mathrm{Pb}$ and not the total concentration of $\mathrm{Cd}, \mathrm{Pb}$ seem to correlate well with the toxicity parameters (Vig et al., 2003). There appear to be no comparable reports in which the effects of heavy metals, singly or in combination, on soil microorganisms in vivo have been compared. Similarly, there is little information on the suppression of growth or tolerance developed by individual microorganisms in vivo with respect to combinations of metals. However, there are some positive and negative interactions between metals upon their toxic effects on microorganisms in vitro.

A variety of methods exists to estimate the size of the microbial biomass in soil. Of these methods, the most simple and rapid is substrate (glucose) induced respiration (SIR), which stimulates a maximal respiratory response from the soil biomass, measured conduct metrically as $\mathrm{CO}_{2}$ evolution, and methods currently available are those involving direct counting in which microorganisms can be variously stained, and relates this respiration to biomass $\mathrm{C}$ (Anderson and Domsch, 2000). Metals are introduced into the environment during mining and refining of ores and from other sources, such as the combustion of fossil fuels, industrial processes, spraying of pesticides, and disposal of industrial and domestic wastes etc. One particular uncertainty is whether the toxic effects of combinations of metals are synergistic, additive, or antagonistic. There have been numerous reviews on the effect of metals on microorganisms (e.g., Trevors et al., 1996) that have dealt mainly with in vitro studies of the biochemical and physiological mechanisms whereby metals exert their effects on microorganisms. Collins and Stotzky (2001) stated that microorganisms interact with metals in various ways: many metals are essential to microorganisms, because they are electron acceptors or cofactors in enzymes, whereas other metals are toxic. Leita et al. (1995) studied influence of $\mathrm{Pb}, \mathrm{Cd}$, and $\mathrm{Tl}$ on microbial biomass survival and activity during a laboratory incubation of soil. In comparison to uncontaminated soil, the microbial biomass $\mathrm{C}$ decreased sharply in soil contaminated with $\mathrm{Cd}$ and $\mathrm{Tl}$, whereas the addition of $\mathrm{Pb}$ did not have any significant inhibitory effect on the level of microbial biomass C. Heavy metals influenced microorganisms by affecting their growth, morphology, and biochemical activities.

The supply of mineralized $\mathrm{C}, \mathrm{N}$ and $\mathrm{P}$ from soil organic matter, the decomposition of plant and animal residues and the maintenance of soil structure are all dependent upon the correct functioning of the soil microbial ecosystem (De Haan et al., 1999). Therefore, it is important to determine and predict the adverse effects of heavy metals and other pollutants on soil microorganisms (Baath, 2002). The short-term effects of $\mathrm{Pb}$ in sand were distinct. In sandy loam, the inhibitory effect was not significant, but after 43 weeks, it had 
increased significantly. In silty loam and clay, no significant inhibitory effects were found. In general, the heavy metals were found to be more toxic during the first eight weeks than after an extended period. It was decreased in this study that toxicity of heavy metals in soil decreases with time. Clay (Dutch clay soils mainly contain illite) as a biotic factor was found to be the dominant factor in decreasing the toxicity of $\mathrm{Pb}$ and to a lesser extent of $\mathrm{Cd}$.

The objectives of present investigation were:

1) To determine whether measurements of microbial biomass $\mathrm{C}$ and $\mathrm{CO}_{2}$ evolution are suitable as bio indicator parameters of soil contamination.

2) To study the effect of heavy metals on microbial biomass, survival and activity in treated soil under laboratory incubations.

3) To study the role of microorganisms in the bioavailability of investigated metal.

\section{MATERIALS AND METHODS Soil and treatments}

The soil samples were collected from the upper $10 \mathrm{~cm}$ of the sandy clay soil. The soil samples were air-dried. The bioavailability and the effect of heavy metals $(\mathrm{Cd}, \mathrm{Pb})$ on $\mathrm{CO}_{2^{-}}$ production and bacterial population were studied. Chemical materials in the form of sodium nitrate $(170 \mathrm{mg} / \mathrm{kg})$, potassium phosphate $(50 \mathrm{mg} / \mathrm{kg})$, and glucose $(3 \mathrm{~g} / \mathrm{kg})$ as sources of $\mathrm{N}, \mathrm{P}$, and $\mathrm{C}$ respectively were added to the soil samples for activating the soil samples.

The soil sample was divided into three groups according to the number of heavy metals used. Each group was divided into three subgroups which were treated with three concentrations of $\mathrm{Cd}$ in $\mathrm{CdCl}_{2}(1.5,3$, and $6 \mathrm{ppm}$ ), or $\mathrm{Pb}$ in the form of $\mathrm{PbCl}_{2}$ (40, 80 and $160 \mathrm{ppm})$. The treated soil samples were incubated for six weeks. The soil samples were collected for measuring the total bacterial counts and the amount of $\mathrm{CO}_{2}$-production after $1^{\text {st }}$ week, $3^{\text {rd }}$ week and $6^{\text {th }}$ week of incubation at $28^{\circ} \mathrm{C}$ the experiment was carried out in triplicates.

For measurement of $\mathrm{CO}_{2-}$ production, a fixed plastic tube containing $50 \mathrm{ml} 10 \mathrm{M} \mathrm{NaOH}$ solution for trapping the evolution of $\mathrm{CO}_{2}$ was placed in the centre of 1.51 glass vessel filled by $0.5 \mathrm{~kg}$ of the heavy metal treated soil sample and vessel was closed tightly. The $\mathrm{NaOH}$ was titrated with $\mathrm{HCl}(1 \mathrm{M})$ to calculate the volume of $\mathrm{CO}_{2}$ of soil respiration, which represented the 1) respiration due to litter decomposition, 2) root respiration, 3) rhizo-microbial espiration (i.e. microbial respiration utilizing $\mathrm{C}$ directly derived from living roots, and 4) microbial respiration utilizing native soil organic matter.

Method of Erdey (1989) was applied for simultaneous determination of $\mathrm{NaOH}$ and $\mathrm{Na}_{2} \mathrm{CO}_{3}$ content in the experimental soil samples. MI -081735-1990 is the Hungarian technical directive method which was used to detect $\mathrm{Cd}, \mathrm{Pb}$ content in the soil samples. Five $\mathrm{g}$ of air-dried soil samples were ground to pass through a $2 \mathrm{~mm}$ stainless steel sieve for use. Soil samples were shaken by $25 \mathrm{~cm}^{3} 1.5 \mathrm{M}$ nitric acid at $20{ }^{\circ} \mathrm{C}$ for two hours. The elemental analysis of the filtrate was performed by jobin-Yvon 24 type ICP atomic emission spectrometer. The study was carried out in three replicates.

\section{Determination of total number of bacteria:}

The total bacterial count was carried out in all soil amendment with different concentrations of $\mathrm{Cd}$ and $\mathrm{Pb}$ Under sterile conditions, serial dilution technique was used for this purpose. 10 $\mathrm{g}$ of fresh soil sample of each soil treatment was suspended with $90 \mathrm{~cm}^{3}$ sterile distilled water. After shaking for 30 min., in rotary shaker, this suspension was diluted gradually to 
$10^{-3}$ and $10^{-5}$ and from each diluted suspensions $1 \mathrm{~cm}^{3}$ was pipette in Petri dish, and thoroughly mixed with Nutrient agar. The developed bacterial colonies were counted after $48 \mathrm{~h}$ incubation at $28^{\circ} \mathrm{C}$. The investigations were done in triplicates.

\section{RESULTS AND DISCUSSION}

The effect of CNP and heavy metals on $\mathrm{CO}_{2}$-production and bacterial population of sandy clay soil was studied in laboratory conditions. This study is concerned with the effect of $\mathrm{CNP}$ and heavy metals $\mathrm{Cd}$, and $\mathrm{Pb}$, on $\mathrm{CO}_{2}$-production as well as bacteria populations of sandy clay soil during one, three and six weeks incubation. After a week incubation, the recovery of $\mathrm{Cd}$ and $\mathrm{Pb}$ concentrations added to CNP treated sandy clay soils was determined in the nitric acid soluble fraction. Data presented in Fig.1.

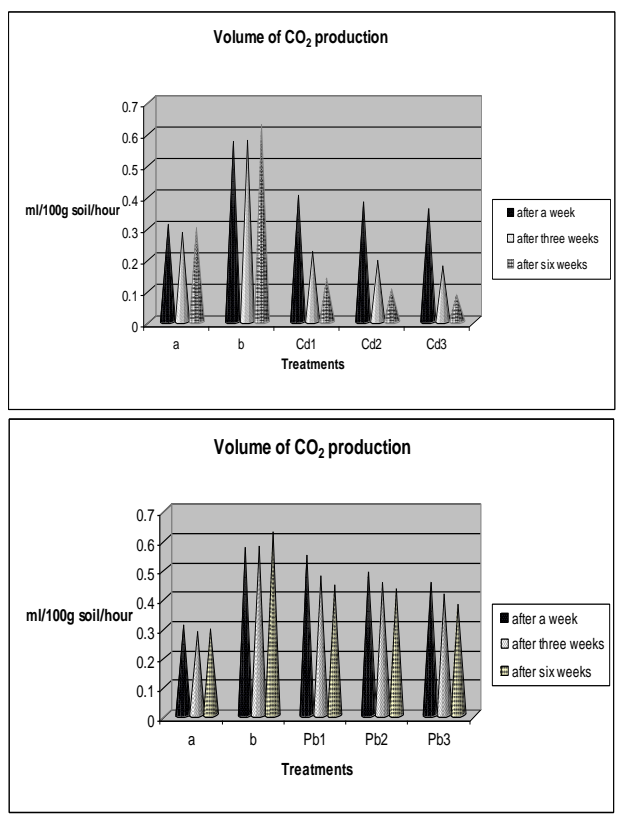

Fig.1: Average of $\mathrm{CO}_{2}$ - production volume at 25 ${ }^{\circ} \mathrm{C}, 0.1 \mathrm{MPa}(\mathrm{ml} / 100 \mathrm{~g}$ soil per an hour) of sandy clay soil treated by CNP and heavy metals for different three periods (a: CNP untreated soil, b: CNP treated soil)

Show that the addition of inorganic forms of $\mathrm{Cd}$ and $\mathrm{Pb}$ significantly increases the mobile $\left(\mathrm{HNO}_{3}\right.$ soluble $)$ fraction of these metals but after week incubation their concentration does not reach the $100 \%$ recovery. It can be observed that the methods used for biomass, $\mathrm{CO}_{2}$ evolution and total bacteria number, are both suitable to be indicators for biomass measurements through which we can have an idea about the soil fertility. It is known that microbial biomass plays an important role in mineral nutrition of soil.

The effect of heavy metal treatments on $\mathrm{CO}_{2}$ reduction in $\mathrm{CNP}$ fertilized soil is showed in Fig.1. It is clear from data presented that CNP treated sandy clay soil showed higher rate of $\mathrm{CO}_{2}-$ production, estimated by $0.57,0.58$ and $0.63 \mathrm{ml} / 100 \mathrm{~g}$ soil/hour, in sandy clay soil comparing with $0.31,0.29$ and 0.30 $\mathrm{ml} / 100 \mathrm{~g}$ soil/hour in CNP sandy clay soil during all three different incubation periods ( $1^{\text {st }}$ week, $3^{\text {rd }}$ week and $6^{\text {th }}$ week).

Data recorded in Fig. 2. Show that CNP treated sandy clay soil samples have higher bacterial population (which are representing in term of $\log$ of bacterial colonies) than in untreated ones during the three different periods $\left(1^{\text {st }}\right.$ week, $3^{\text {rd }}$ week and $6^{\text {th }}$ week).
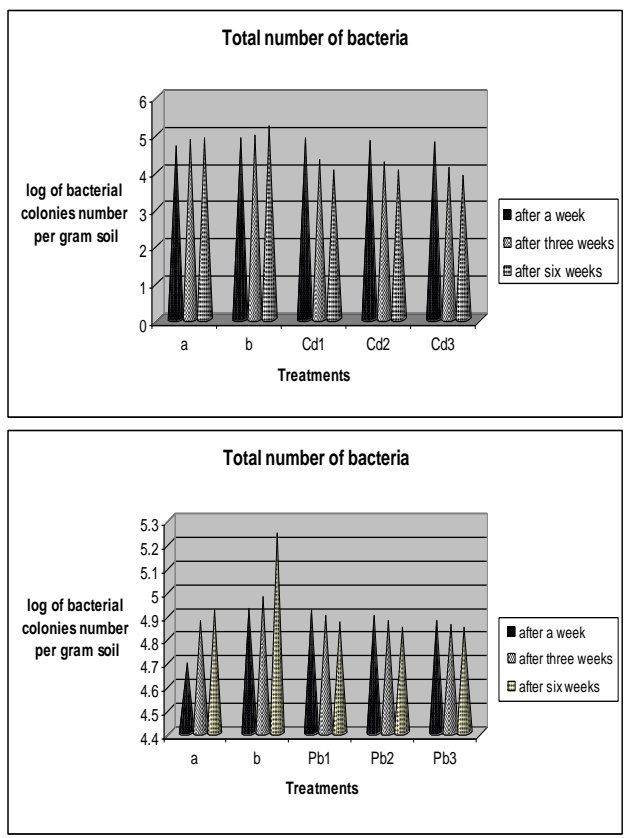

Fig.2: Average of $\log$ of total bacterial number of sandy clay soil treated by CNP and heavy metals after different three periods (a: CNP untreated soil, b: CNP treated soil). 
These previous results are in accordance with the results found by De Haan et al. (1999) who reported that the supply of mineralized $\mathrm{C}, \mathrm{N}$ and $\mathrm{P}$ from soil organic matter, the decomposition of plant and animal residues and the maintenance of soil structure are all dependent upon the correct functioning of the soil microbial ecosystem. The beneficial effects of sewage sludge due to the extra organic matter $\mathrm{N}$ or $\mathrm{P}$ supplied may be short lived. These results are also in accordance with investigation of Hossain et al. (2005). Hossain et al. (2005) have discussed the effects of fertilizer. It was reported that only the lime plus $\mathrm{P}$ and $\mathrm{N}$ plus $\mathrm{P}$ treatments significantly affected soil microbial biomass $\mathrm{C}$ content. The $\mathrm{N}$ plus $\mathrm{P}$ treatment increased biomass $\mathrm{C}$ content. Microbial specific respiratory activity was higher in the unfertilized treatments. Nannipieri et al. (1990) stated that the changes in $\mathrm{CO}_{2^{-}}$ evolution were related to glucose concentrations of mineral nutrients. Higher initial rates of $\mathrm{CO}_{2}$-evolution were noted after the addition of $\mathrm{P}$ and glucose to $\mathrm{N}$ amended soil at $\mathrm{C}$ : $\mathrm{P}$ ratios greater than 30:1. It's also shown from such data presented in Fig. 1. Those heavy metals, $\mathrm{Cd}$ and $\mathrm{Pb}$ have significant effect on $\mathrm{CO}_{2}$-production of tested sandy clay soil at different incubation periods $\left(1^{\text {st }}\right.$ week, $3^{\text {rd }}$ week, and $6^{\text {th }}$ week).

$\mathrm{Pb}$ at different concentrations, 40,80 , and $160 \mathrm{mg} / \mathrm{kg}$ have the smallest effect on decreasing $\mathrm{CO}_{2-}$ production either in sandy clay soil incubated at different periods. It can be shown also from data that $\mathrm{Cd}$ has higher effects in decreasing the amount of $\mathrm{CO}_{2}$-production at the different concentration used, 1.5, 3, and $6 \mathrm{ppm}$ for $\mathrm{Cd}$ either in sandy clay soil at the three different periods. Baath (2002) studied the effect of heavy metals in soil microbial processes and populations. He established that the relative toxicity of different metals decreased in the order $\mathrm{Cd}>\mathrm{Cu}>\mathrm{Zn}>\mathrm{Pb}$. His results were similar to my result in which my investigation showed that the relative toxicity of tested metals decreased in the order $\mathrm{Pb}>\mathrm{Cd}$.

A significant effect of heavy metals, lead and cadmium on bacterial population has been found in CNP treated or untreated soils (Fig. 2.). It is shown that $\mathrm{Cd}$ has much more significant effect in decreasing bacterial population than $\mathrm{Pb}$ that has a little effect. It is also clear that the higher concentration of $\mathrm{Pb}$ and $\mathrm{Cd}$ cause decreases in total bacterial population. Concerning the effect of $\mathrm{Pb}$ and $\mathrm{Cd}$ on the $\mathrm{CO}_{2}$-production and its relation to the sampling time, it is obvious that there is a clear trend. In the two heavy metal treatments, $(\mathrm{Pb}$ and $\mathrm{Cd}$ ), the highest $\mathrm{CO}_{2}$-production was measured after the $1^{\text {st }}$ week incubation followed by the $3^{\text {rd }}$ and $6^{\text {th }}$ week respectively. The same effect was found for the bacterial population. This result is in accordance with the result of Leita et al. (1995) who reported that the addition of $\mathrm{Pb}$ did not have any significant inhibitory effect on the level of microbial biomass $\mathrm{C}$.

\section{CONCLUSION}

1- The inhibitory effect of heavy metals applied in my experiment $(\mathrm{Pb}$ and $\mathrm{Cd})$ on $\mathrm{CO}_{2}$-production and total number of microorganisms is significant.

2- Measurement of $\mathrm{CO}_{2}$ is appropriate indicator for $\mathrm{Pb}$ and $\mathrm{Cd}$ contamination.

\section{REFERENCES}

Anderson, J.P.E. and Domsch, K.H. (2000): A physiological method for the quantitative measurement of microbial biomass in soils. Soil Biol. Biochem., 10: 215-221.

Baath, E. (2002): Effects of heavy metals in soil metals on microbial processes and population (a review). Water Air Soil Pollut., 47: 335-346. 
Bayoumi Hamuda, H.E.A.F. and Kecskés, M. (2008): Correlation between the efficiencies of $\mathrm{CO}_{2}$ release, FDA, and dehydrogenase activity in the determination of the biological activity in soil amended with sewage sludge. Az MTA Szabolcs-Szatmár-Bereg Megyei Tudományos Testülete 12 éves Tudományos Ülés (Konferencia kiadvány). Nyíregyháza, Hungary. 1. Kötet, pp: 11-16.

Cheng, W. (1999): Rhizosphere feedbacks in elevated $\mathrm{CO}_{2}$. Physiol., 19: 313-320.

Collins, Y.E. and Stotzky, G. (2001): Influence of heavy metals on the electro-kinetic properties of bacteria. Am. Soc. Microbiol., pp. 229.

De Haan, F.A.M., Bourg, A.C.M., Brookes, P.C., Verstraete, W., van Riemsdijk, W.H., van der Zee, S.E.A.T.M., Giraldez, J.V. and McGrath S.P. (1999): Soil quality assessment. State of the art report on soil quality. Final report to the C.E.E. DirectorateGeneral XII, Science, Research and Development Directorate E., Environment and Non-Nuclear Energy Contract EV4A/0008/NL.

Erdey, L. (1989): Bevezetés a kémiai analízisbe, második rész. pp. 95-97.

Hossain, A.K.M.A., Raisson, R.J. and Khanna, P.K. (2005): Effects of fertilizer application and fire regime on soil microbial biomass carbon and nitrogen, and nitrogen mineralization in an Austrialian subalpine eucalypt forest. Biol. and Fertil. of Soils, 19: 246-252.

Leita, L., De-Nobil, M., Muhlbachova, G., Mondini, C. and Zerbi, G. (1995): Bioavailability and effects of heavy metals on soil microbial biomass survival during laboratory incubation. Biol. and Fertl. of Soils. 19: 103-108.

MI-08-1735-1990 (1990). A szennyvízben megenhető káros és mérgező komponensek határértékei szántóföldi szennyvízhasznosítás esetén.

Nannipieri, P., Grego, S. and Ceccanti, B. (1990): Ecological significance of the biological activity in soil. Soil Biochem., 6: 293-355.

Pajari, B. (1995): Soil $\mathrm{CO}_{2}$ efflux in a poor upland site of Scots pine stand subjected to elevated temperatures and atmospheric carbon concentration. Plant and Soil, 169: 563-570.

Trevors, J.T., Stratton, G.W. and Gadd, G.M. (1996): Cadmium transport, resistance, and toxicity in bacteria, algae, and fungi. Can. J. Bacteriol., 32: 447.

Vig, K. Megharaj, M., Sethunathan, N. and Naidu, R. (2003): Bioavailability and toxicity of cadmium to microorganisms and their activities in soil: a review. Adv. Environ. Res., 8: 121-135.

\section{ARABIC SUMMARY}

$$
\begin{aligned}
& \text { تأثير العناصر الثقيلة على عمليات كثافة الاحياء الدقيقة فى التربة } \\
& \text { كلية الزراعة - جامعة سبدهام السلام ـ ليبيا } \\
& \text { ان تأثير العناصر الثقيلة المختلفة السامة تمت در استها فى انتاج ثانى اكسيد الكربون للآحياء الدقيقة فى التى } \\
& \text { التربة الرملية الطينية غير المزروعة فى صورة نتر ات الصوديوم وفوسفات البوتاسيوم و الجلوكوز بصورة } \\
& \text { متتابعة ولقد تمت معالجة التربة عن طريق ) ( P,C,N). }
\end{aligned}
$$

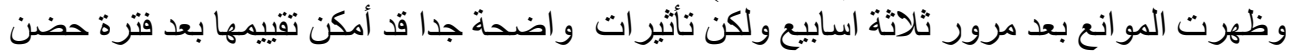

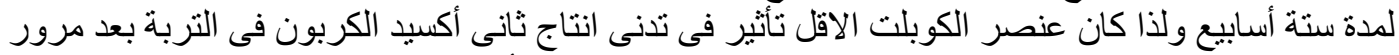

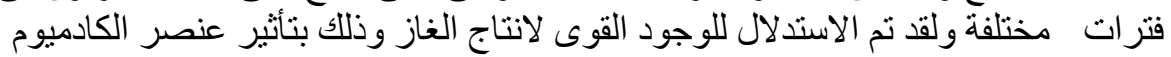

